\title{
Study of carbohydrates present in the cladodes of Opuntia ficus-indica (fodder palm), according to age and season
}

\author{
Estudo dos carboidratos presentes nos cladódios de Opuntia ficus-indica (palma forrageira), \\ de acordo com sua idade e sazonalidade
}

Erika Maria de Oliveira RIBEIRO ${ }^{1}$, Nicácio Henrique da SILVA³, José Luiz de LIMA FILHO ${ }^{1}$, Júlio Zoe de BRITO² $^{2}$ Maria da Paz Carvalho da SILVA ${ }^{1 *}$

\begin{abstract}
Types and content of carbohydrates were evaluated by chemical (spectrophotometric assay) and physicochemical (Thin Layer Chromatography TLC and High Performance Liquid Chromatography - HPLC) methods in some Opuntia ficus-indica varieties according to age and season. The samples comprised four varieties of palm (giant, copena F1, clone 20, and round palm). The results demonstrated that the four varieties of palm contain a good quantity of neutral and acid sugars in both summer and winter seasons. However, samples collected in the summer presented a higher content of carbohydrates specially glucose, fructose, galactose, xylose, and arabinose. The tertiary cladode (old cladode) presented almost the double content of sugar found in the quaternary cladodes (young cladodes). Pectic polysaccharides were sequentially extracted with water at $60^{\circ} \mathrm{C}$, and EDTA at $60^{\circ} \mathrm{C}$ solution resulting in Water-Soluble Pectin (WSP) and a Chelating-Soluble Pectin (CSP) respectively. Galacturonic acid was detected in the fractions WSP and CSP. However, the fraction CSP presented the highest content of sugar acid.
\end{abstract}

Keywords: Opuntia ficus-indica; carbohydrates; pectin.

\section{Resumo}

Tipos e conteúdo de carboidratos foram avaliados por métodos químicos (ensaios espectrofotométricos) e físico-químicos (Cromatografia de Camada Delgada - CCD e Cromatografia Líquida de Alta Eficiência - CLAE), em algumas variedades de Opuntia fícus-indica. As amostras estudadas compreenderam quatro variedades de palma (gigante, copena F1, clone 20 e palma redonda). Os resultados demonstraram que as quatro variedades de palma contêm uma boa quantidade de açúcares neutros e ácidos nas estações do ano verão e inverno. Entretanto, amostras coletadas no verão apresentaram um alto conteúdo de carboidratos, especialmente glicose, frutose, galactose, xilose e arabinose. $\mathrm{O}$ cladódio terciário (cladódio mais antigo) apresentou quase o dobro do conteúdo de açúcar encontrado nos cladódios quaternários (cladódios mais jovens). Polissacarídeos pécticos foram sequencialmente extraídos com água a $60^{\circ} \mathrm{C}$ e solução de EDTA a $60^{\circ} \mathrm{C}$, resultando em uma Pectina Solúvel em Água (PSA) e Pectina Solúvel em Quelante (PSQ), respectivamente. Ácidos galacturônicos foram detectados em frações PSA e PSQ. Entretanto a fração PSQ apresentou o mais alto conteúdo de açúcar ácido.

Palavras-chave: Opuntia ficus-indica; carboidratos; polissacarídeos pécticos.

\section{Introduction}

In the last years, the palm (Opuntia ficus-indica) has been used in some countries as vegetable or for the consumption of its natural fruits, which is due to its increased nutritional value. This could be attributed to its rich content of vitamin, A which is a scarce nutrient in the diet in Northeastern Brazil and to the high amount of carbohydrates present (DORNELAS; BARBOSA, 2003). In addition to these nutrients, the palm also presents important amount of minerals such as: $\mathrm{Ca}^{+2}, \mathrm{Mg}^{+2}, \mathrm{Na}^{+}$, $\mathrm{K}^{+}$, and $\mathrm{Fe}^{+2}$ and fibers: lignin, cellulose, hemicellulose, and pectin that together with amino acids help to eliminate toxins such as ammonia and free radicals (SÁENZ et al., 1997).

Opuntia ficus-indica is widely cultivated in the semiarid countries in the Americas mainly to feed cattle, goat, and sheep. It can be easily found in Pernambuco, Brazil. It is constituted of $90 \%$ water and $10 \%$ dry matter (DORNELAS; BARBOSA, 2003).

The cladodes of this cactus (modified stems) have proved an excellent nutritional fiber source (SÁENZ et al., 1997). The fibers content depends on some factors such as the variety and age of the plant in the harvest period, soil, and climate. These cladodes are used as vegetables; animal food; medicinal plant for diarrhea and hiperlipidemy, anti-inflammatory; and cosmetics (lotions for the body and deodorants).

Malainine et al. (2003) found carbohydrates as the main constituent of the palm cladodes. Harlay (1902), Amim et al. (1970) found neutral sugars such as: D-galactose and L-arabinose

Recebido para publicação em 2/9/2008

Aceito para publicação em 8/7/2009 (003818)

Laboratório de Imunopatologia Keizo Asam, Departamento de Bioquímica, Universidade Federal de Pernambuco - UFPE, CEP 50921-160, Recife - PE, Brasil,

E-mail: mariadapazc@gmail.com

2 Instituto Agronômico de Pernambuco, Empresa Pernambucana de Pesquisa Agropecuária (Presidência), CEP 50000-000, Recife - PE, Brasil

${ }^{3}$ Departamento de Bioquímica, Universidade Federal de Pernambuco - UFPE, CEP 50921-160, Recife - PE, Brasil

${ }^{*}$ A quem a correspondência deve ser enviada 
in the mucilage of Opuntia. Other authors have suggested that the mucilage was acidic containing L-arabinose, D-galactose, L-rhamnose, and D-galacturonic acid (ANDERSON; SANDS; STURGIS, 1925; SANDS; KLAAS, 1929). Parikh and Jones (1965) have reported that the mucilage of Opuntia fulgida consisted of a backbone of $\beta(1 \rightarrow 3)$-linked galactose units with branches on carbon $\mathrm{C}_{6}$ containing $\mathrm{D}$-galacturonic acid, $\mathrm{D}$-galactose, $\mathrm{D}$-xylose, $\mathrm{L}$-rhamnose, and L-arabinose units.

The most abundant polysaccharides in the cell wall of many higher plants are pectins. They are localized in the middle lamellae where they regulate intercellular adhesion. They also influence growth, development and senescence (HABIBI et al., 2004). Pectins are a family of complex polysaccharides (heteropolysaccharides) which comprise a diversity of carbohydrate residues. Similarly, the majority of other plant polysaccharides, the pectins, are polydisperse in the composition and molecular size, and they are heterogeneous with respect to the chemical structure and molecular weight. Its composition varies with the source and the conditions of the extraction, position, and other ambient factors (CHANG et al., 1994).

Pectins have a number of applications in the pharmaceutical, cosmetic, and food industries, and new sources of these polysaccharides are constantly sought (MAY, 1990; NOVOSEL'SKAYA et al., 2000).

In the last years, the demand for carbohydrates from natural sources of easy culture and that present a higher productivity of biomass has been increased (MENEZES; SIMÕES; SAMPAIO, 2005). Thus, these long term stable natural sources can compete commercially with others. IPA (Agricultural Research Institute) initiated in the 1980s a program of genetic palm improvement introducing and generating new clones and increasing its germoplasm bank with about 1.400 entrances. Therefore, since the palm is widely found in the northeastern backlands, particularly in Pernambuco, and that it can tolerate the drought season for a long time due to the amount of water in its stem, it is considered of great importance. Hence, it is necessary to study the carbohydrates present in its cladodes since it is the main source of food for cattle, sheep, and goat, and also since it is used as a medicinal plant and even in cooking. The objective of the present work was to compare types and content of carbohydrates of the palm cultivated in the countryside according to its age and season.

\section{Materials and methods}

\subsection{Materials}

The cladodes used in this work were harvested in the period of drought and rain in the State of Pernambuco, Northeastern Brazil, in the Experimental Station of Caruaru - PE, which is part of the Agriculture Research Institute (IPA).

The weather of the semiarid region presents a temperature between 22 to $30{ }^{\circ} \mathrm{C}$ with sunny days, cold nights, and little humidity with an average annual temperature of $24^{\circ} \mathrm{C}$ and annual pluviometric index of about $609 \mathrm{~mm}$; the months of June and July constitute the rainy season.
The palm plant belongs to the Cactaceae family, Opuntia genus, ficus-indica specie. They are clones selected by the IPA for being more productive than the others cultivated in the same region since the milk basin of Pernambuco State has in the palm its main source of water. The analyzed varieties were: Copena F1, Giant Palm, Clone 20, and Round Palm.

\subsection{Methods}

\section{Preparation of the palm extract}

The extracts were obtained from tertiary cladodes (old cladodes) and quaternary cladodes (young cladodes) of four varieties of palm. The palm pricks were removed, washed with distilled water, dried, cut in small pieces $(4.0 \mathrm{~cm}$ length, $3.0 \mathrm{~cm}$ width and $2.0 \mathrm{~cm}$ of thickness), and triturated in an industrial blender to get the extract. The extract obtained was submitted to two procedures: 1) centrifuged at $16,000 \times \mathrm{g}$ for 15 minutes, and the supernatant was used for the determination of carbohydrates; 2) $10 \mathrm{~g}$ of extract ground was dried at $50{ }^{\circ} \mathrm{C}$ for isolation of pectic polysaccharides.

\section{Preparation of Cell-Wall Material (CWM)}

Fats, waxes, and oils were removed from the cladode powder by refluxing in a Soxhlet apparatus for 24 hours with 38:62 (v/v) toluen-ethanol. The resulting mucilage was removed from the defatted cladode residue by treatment with water $(2 \times 2$ hours $)$ at room temperature in order to prepare CWM (HABIBI et al., 2004).

\section{Isolation of pectic polysaccharides}

Pectic polysaccharides were sequentially extracted from CWM by water $\left(2 \times 2\right.$ hours at $\left.60^{\circ} \mathrm{C}\right)$ and aqueous solution of calcium chelator agent $0.5 \%$ EDTA $\left(2 \times 2\right.$ hours at $\left.60^{\circ} \mathrm{C}\right)$. All extracts were precipitated with ethanol (4 volumes) resulting in a Water-Soluble Pectin (WSP) and a Chelating-Soluble Pectin (CSP), respectively. The extraction scheme is given in Figure 1 (HABIBI et al., 2004).

\section{Determination of neutral sugars}

The content of sugars was determined by using phenol sulphuric acid, as described by Dubois et al. (1956). The following experiments were carried out in triplicate.

\section{Determination of reducing sugar}

The quantification of reducing sugars was carried out by using Dinitrosalicyclic acid method described by Bernfeld (1955). The samples before and after hydrolysis were both assessed. The hydrolysis was proceeded with concentrated $\mathrm{HCl}$ with 2 hour intervals at $100^{\circ} \mathrm{C}$ and neutralized with $20 \% \mathrm{NaOH}$. The following experiments were carried out in triplicate.

\section{Determination of uronic acid in raw and pectin extracts}

The uronic acid was determined by using the carbazol method described by Dische (1974). The following experiments were carried out in triplicate. 


\section{Thin Layer Chromatography (TLC)}

The chromatography of the extracts was carried out by using silica gel plates. The elution system used for monosaccharides was acetone/n-butanol/water (80:10:10 v/v/v), and was revealed with: $2 \%$ diphenylamine prepared in acetone; $2 \%$ aniline prepared in acetone and 85\% orthophosphoric acid (5:5:1 $\mathrm{v} / \mathrm{v} / \mathrm{v})$. The standards used were: galactose, xylose, arabinose, glucose, fructose, rhamnose, and sucrose. For the acid sugars (glucuronic acid and galacturonic acid) the elution system used was chloroform/ methanol/ acetic acid/ water (40:40:10:10 $\mathrm{v} / \mathrm{v} / \mathrm{v} / \mathrm{v}$ ) revealed with: $2 \%$ diphenylamine prepared in acetone; $2 \%$ aniline prepared in acetone, and $85 \%$ orthophosphoric acid $(5: 5: 1 \mathrm{v} / \mathrm{v} / \mathrm{v})$. In addition, the sugars were detected by using thin layer chromatography of the pectic extract from the giant palm in the same conditions.

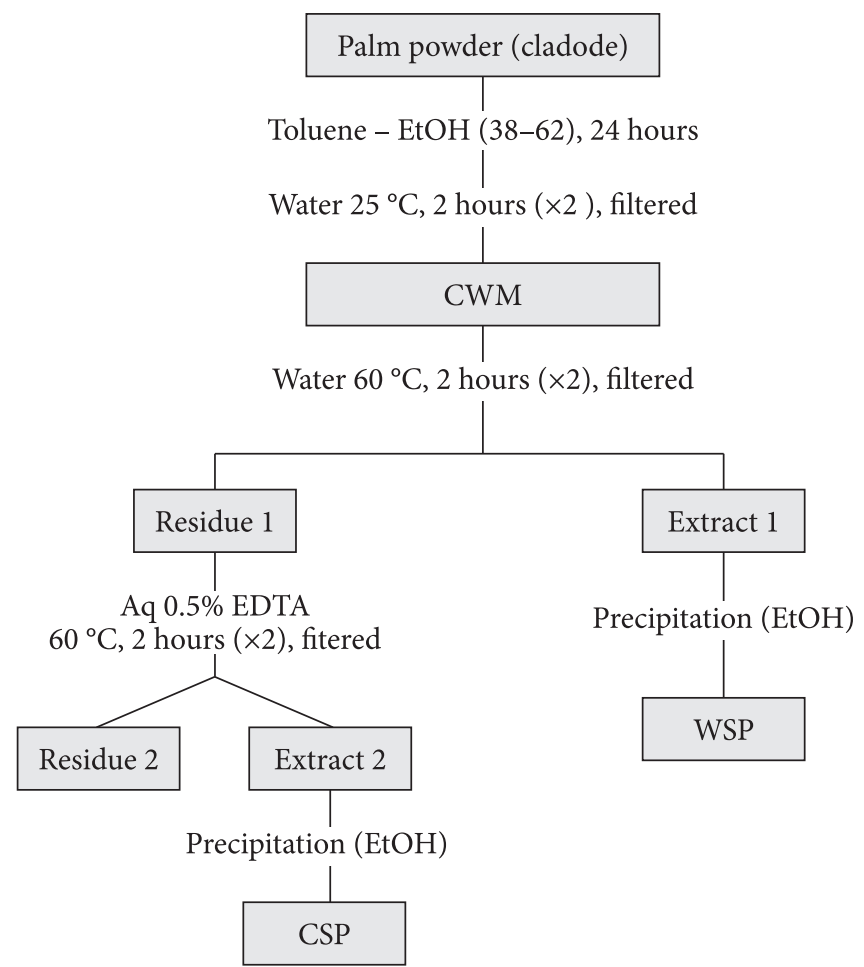

Figure 1. Extraction of pectic polysaccharides from giant, round, copena F1 and clone 20 palm cladodes. Where: CWM = Cell Wall Material, WSP $=$ Water-Soluble Pectin, CSP $=$ Chelating-Soluble Pectin.

\section{High Performance Liquid Chromatography (HPLC)}

The liquid chromatography of the extracts was carried out by using the following conditions: Shimadzu/Waters (Japan/ USA) chromatograph, aminex column (HPX- 87C, Biorad), refractive index detector, water as mobile phase, flow rate of $0.6 \mathrm{~mL} /$ minute, injection volume of $20 \mu \mathrm{L}$, and Borwin Software program (France). The standards used were: galactose, xylose, arabinose, glucose, fructose, rhamnose, sucrose, and uronic acid.

\section{Statistical analyses}

The statistical analyses were evaluated by using the Origin 7.5 Software. Variance analyses were performed by comparing the differences between the averages using the Tukey test at $5 \%$ level of probability.

\section{Results and discussion}

The results of the eight samples evaluated with regard to the total concentration of sugars are summarized in Table 1 . The existence of significant difference can be observed $(\mathrm{p}<0.05)$ among the averages of the majority of the samples, exception for the quaternary round palm average in the dry and rainy season.

The occurrence of significant differences among the varieties of palm indicates that the amount of total sugar in the oldest palms was higher presenting almost the double of the amount of sugar found in the quaternary cladode in both dry and rainy seasons. This data presents a similarity to that considered by Pimienta (1990), who studying the composition of the Opuntia cladodes obtained the amount of raw fiber of the primary, secondary, and tertiary cladodes $(12,0 ; 14,5 ; 17,0 \%)$ respectively. Thus, it can be said that the age of the cladodes influences its chemical composition and that the amount of fiber increases with the cladodes age.

The significant differences among the four varieties, were already expected in view of that it deals with materials of fodder palm that possess opposite phenotypic characteristics. This situation, according Cruz and Regazzi (1994), is an indication favorable enough to the study of the genetic divergences.

Table 1. Content of total sugar and uronic acid in the dry and rainy seasons from the four varieties of Opuntia fícus indica.

\begin{tabular}{|c|c|c|c|c|}
\hline \multirow[t]{2}{*}{ Types of palm } & \multicolumn{2}{|c|}{ Total sugar $\left(\mathrm{mg} \cdot \mathrm{mL}^{-1}\right)$} & \multicolumn{2}{|c|}{ Uronic acid (mg.mL $\left.\mathrm{mL}^{-1}\right)$} \\
\hline & $\begin{array}{c}\text { Dry season } \\
\text { Mean } \pm \text { Deviation }\end{array}$ & $\begin{array}{c}\text { Rainy season } \\
\text { Mean } \pm \text { Deviation }\end{array}$ & $\begin{array}{c}\text { Dry season } \\
\text { Mean } \pm \text { Deviation }\end{array}$ & $\begin{array}{c}\text { Rainy season } \\
\text { Mean } \pm \text { Deviation }\end{array}$ \\
\hline Tertiary giant palm & $21.58 \pm 0.035$ & $24.11 \pm 0.042$ & $2.78 \pm 0.000$ & $3.40 \pm 0.000$ \\
\hline Quaternary giant palm & $12.76 \pm 0.095$ & $13.80 \pm 0.049$ & $4.00 \pm 0.035$ & $2.11 \pm 0.051$ \\
\hline Tertiary round palm & $29.04 \pm 0.121$ & $18.97 \pm 0.00$ & $5.81 \pm 0.276$ & $2.82^{\star * \star} \pm 0.014$ \\
\hline Quaternary round palm & $15.25^{\star} \pm 0.220$ & $15.15^{\star} \pm 0.00$ & $3.89 \pm 0.127$ & $2.66^{\star * *} \pm 0.071$ \\
\hline Tertiary copena F1 & $20.19 \pm 0.220$ & $15.32 \pm 0.092$ & $5.43^{\star *} \pm 0.127$ & $2.57^{* * * *} \pm 0.000$ \\
\hline Quaternary copena F1 & $14.7 \pm 0.000$ & $14.46 \pm 0.049$ & $4.81^{\star \star} \pm 0.311$ & $2.49^{* * \star \star} \pm 0.056$ \\
\hline Tertiary clone 20 & $27.94 \pm 0.145$ & $23.39 \pm 000$ & $7.95 \pm 0.000$ & $3.99 \pm 0.042$ \\
\hline Quaternary clone 20 & $11.56 \pm 0.110$ & $15.80 \pm 0.092$ & $4.50 \pm 0.000$ & $2.53 \pm 0.113$ \\
\hline
\end{tabular}

Followed means of the ${ }^{*}{ }^{* *},{ }^{* *},{ }^{* * *}$, do not differ between itself for the test of Tukey $(\mathrm{p}<0,05)$. 
In the analysis of the amount of reducing sugar obtained before and after acid hydrolysis for 2 hours, it was verified that Copena F1 of the dry season was the variety that contained a highest amount, while in the rainy season the round palm was the one that distinguished itself, and this amount increased in the hydrolysed extract of all varieties of palm in both seasons (Figure 2).

In the Table 1, the results related to the amount of uronic acid are also presented. The oldest cladodes in the dry season presented a higher amount of this acid sugar, with exception of the tertiary giant palm. The four varieties of palm presented excellent concentrations of uronic acid. This high content of uronic acid is in accordance with Habibi et al. (2004), who studying the structural characteristics of pectic polysaccharides from the Opuntia ficus-indica (fruit skin) obtained an amount of uronic acid of $35.6 \%$ in the material of the cellular wall indicating the presence of an important amount of pectic polymers.

The sugars visualized by using TLC and HPLC are presented in Table 2 and Figure 3, respectively. It was observed in Table 2, a variation in the type of sugar in the eight samples analyzed. However, based on all standards used, sugars were detected with exception of rhamnose. These results are in accordance with other researchers' findings, who studying varieties of Opuntias have found important contradictions in its results. Therefore, for some authors, the mucilage was neutral mainly the one containing D-galactose and L-arabinose residues (HARLAY, 1902). Other authors have shown that the mucilage was acidic and contained L-arabinose, D-galactose, L-ramnose, and D-galacturonic acid (ANDERSON; SANDS; STURGIS, 1925; SANDS; KLAAS, 1929).

Table 2. Types of sugars found in the four varieties of Opuntia ficus indica by Thin Layer Chromatography (TLC).

\begin{tabular}{|c|c|c|c|c|c|c|c|c|}
\hline Types of palm & Gal & Xyl & Ara & Glc & Fru & Rha & Suc & Uronic acid \\
\hline R.TGP & - & - & + & - & + & - & - & + \\
\hline H.TGP & - & + & - & + & - & - & + & - \\
\hline R.QGP & + & - & - & - & + & - & - & + \\
\hline H.QGP & + & - & - & + & - & - & + & - \\
\hline R.TRP & + & - & - & + & + & - & - & + \\
\hline H.TRP & + & + & - & - & + & - & + & - \\
\hline R.QRP & + & - & - & + & + & - & - & + \\
\hline H.QRP & + & - & - & - & - & - & + & - \\
\hline R.TCF1 & - & - & - & + & + & - & - & + \\
\hline H.TCF1 & - & + & - & + & + & - & + & - \\
\hline R.QCF1 & - & - & - & + & + & - & - & + \\
\hline H.QCF1 & - & - & - & + & + & - & + & - \\
\hline R.TCLONE20 & - & - & - & + & + & - & - & + \\
\hline H.TCLONE20 & + & + & - & - & + & - & + & - \\
\hline R.QCLONE20 & - & - & - & + & + & - & - & + \\
\hline H.QCLONE20 & + & - & - & - & + & - & + & - \\
\hline \multicolumn{9}{|c|}{$\begin{array}{l}\text { R.TGP = Raw tertiary giant palm; H.TGP = Hidrolysed tertiary giant palm; R.QGP = Raw } \\
\text { quaternary giant palm; H.QGP = Hidrolysed quaternary giant palm; R.TRP = Raw tertiary } \\
\text { round palm; H.TRP = Hidrolysed tertiary round palm; R.QRP = Raw quaternary round } \\
\text { palm; H.QRP = Hidrolysed quaternary round palm; R.TCF1 = Raw tertiary copena } \\
\text { F1; H.TCF1 = Hidrolysed tertiary copena F1; R.QCF1 = Raw quaternary copena F1; } \\
\text { H.QCF1 = Hidrolysed quaternary copena F1; R.TCLONE20 = Raw tertiary clone 20; } \\
\text { H.TCLONE20 = Hidrolysed tertiary clone 20; R.QCLONE20 = Raw quaternary clone } \\
\text { 20; H.QCLONE20 = Hidrolysed quaternary clone 20; Gal = Galactose; Xyl = Xylose; } \\
\text { Ara = Arabinose; Glc = Glucose; Fru = Fructose; Rha = Rhamnose; Sac = Sucrose; } \\
(+)=\text { Presence of carbohydrates; }(-)=\text { Absence of carbohydrates. }\end{array}$} \\
\hline
\end{tabular}

Majdoub et al. (2001); Medina-torres et al. (2000) showed that the mucilage contained uronic acids, rhamnose, arabinose, galactose, and xylose.

Parikh and Jones (1965) said that the mucilage of the Opuntia fulgida consisted of a main structure of galactose joined by a glicosidic linkage $\beta(1 \rightarrow 3)$ with ramifications in the C-6 that contains D-galacturonic acid, D-galactose, D-xylose, $\mathrm{L}$-rhamnose, and units of $\mathrm{L}$-arabinose.

Table 2 also shows that rhamnose was not detected in any variety of Opuntia. This result corroborates the findings of Forni, Penci and Polesello (1994). However, some authors (ANDERSON; SANDS; STURGIS, 1925; SANDS; KLAAS, 1929; PARIKH; JONES, 1965; AMIM et al., 1970) identified rhamnose in other varieties of Opuntia. This absence of rhamnose is explained by Habibi et al. (2004), who studying the structural characteristics of pectic polysaccharides of the Opuntia ficusindica prickly skin fruit could affirm that this is related to the wealth of the Opuntia in pectic polysaccharides. They showed that the pectins are a family of complex polysaccharides which
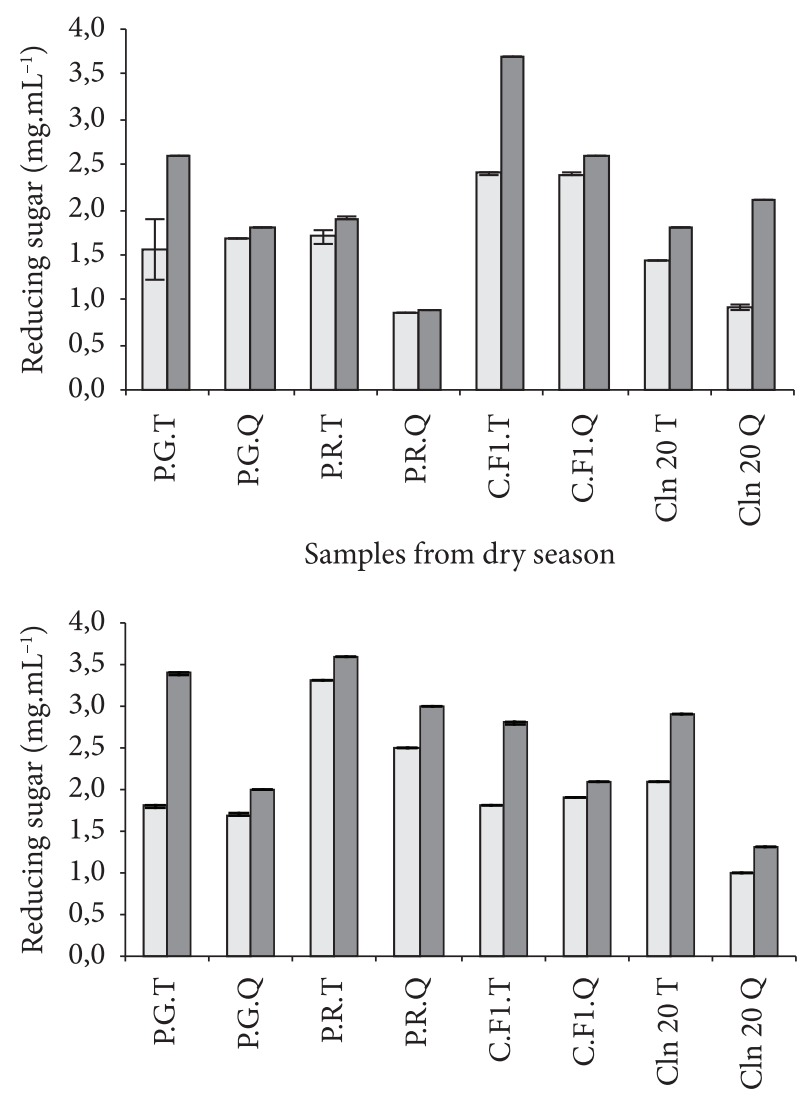

Samples from rainy season

$\square$ Raw extract $\square$ Hidrolysed extract

Figure 2. Content of reducing sugar of the dry and rainy seasons from the four varieties of Opuntia ficus-indica. TGP = Tertiary Giant Palm; QGP = Quaternary Giant Palm; TRP = Tertiary Round Palm; QRP = Quaternary Round Palm; TCF1 = tertiary copena F1; QCF1 = Quaternary Copena F1; TCln20 = Tertiary Clone 20; QCln20 = Quaternary Clone 20 . 
Ribeiro et al.
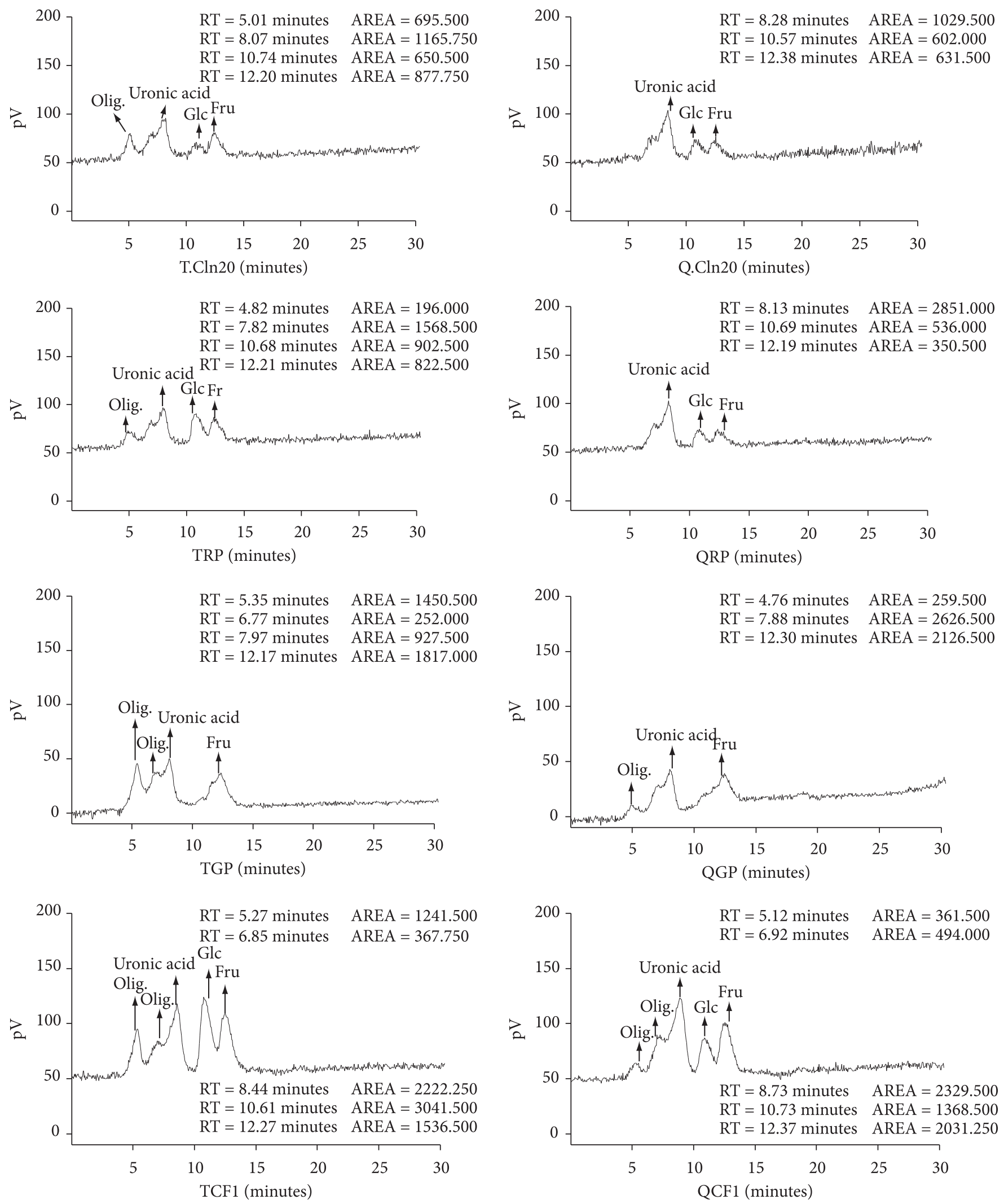

Figure 3. High performance liquid chromatography (HPLC) of the raw samples. Conditions: chromatograph Shimadzu/Waters, column aminex HPX-87C, refractive index detector, mobile phase water, flow rate $0.6 \mathrm{~mL} /$ minute, injection volume $20 \mu \mathrm{L}$. Glucose - Glc, fructose - Fru, oligosaccharides - Olig, uronic acid - Uronic acid, tertiary clone 20 - T.Cln20, quaternary Q.Cln20, tertiary round palm - TRP, quaternary round palm - QRP, tertiary giant palm - TGP, quaternary giant palm - QGP, tertiary copena F1 TCF1, quaternary copena F1 - QCF1. 
contains D-galacturonic acid residues joined by linkage $(1 \rightarrow 4)$, partially esterified and occasionally interrupted by the presence of rhamnose, also presenting lateral chains esterified with galactose, arabinose, xylose, and fructose.

The chromatograms obtained by HPLC presented in Figure 3 and the results detected by TLC in Table 2 show the presence of uronic acid in the four varieties of Opuntia, the same spots were visualized in raw extracts thus justifying the high amount of the acid sugar. These results are in accordance with those of Saag et al. (1975), who analyzing the composition of the gotten mucilage of four different species of cactis: Opuntia monocantha, Opuntia nopalea-coccinillifera, Cereus peruvianos, and Wigginsia erinacea, identified by paper chromatography, galacturonic acid as one of the main components. Furthermore, Table 2 shows the presence of sucrose only in hydrolysed extracts, thus indicating a small amount of sucrose in the palm. Similar result was obtained by Lercker, Lerici and Campela (1976), who identified in the fruit of the India fig (Cactus Opuntia) sucrose in very low amount in relation to the Glucose and Fructose.

Figure 1 shows the extraction procedure of pectics polysaccharides. The different fractions presented a high amount of galacturonic acid (Table 3). Among all varieties, the Chelating-Soluble Pectin (CSP) fraction contained the highest amount of galacturonic acid. Similar results were observed by Habibi et al. (2004) analyzing the skin of fruit from Opuntia.

Table 3 exhibits the amount of galacturonic acid obtained from the palm varieties according to age. The results demonstrated that the tertiary cladodes presented concentrations of galacturonic acid higher than the quaternary cladodes in both fractions, except for the tertiary giant palm. Xylose and arabinose were the sugars detected in the chelating and soluble in water fractions of pectin (Figure 4).

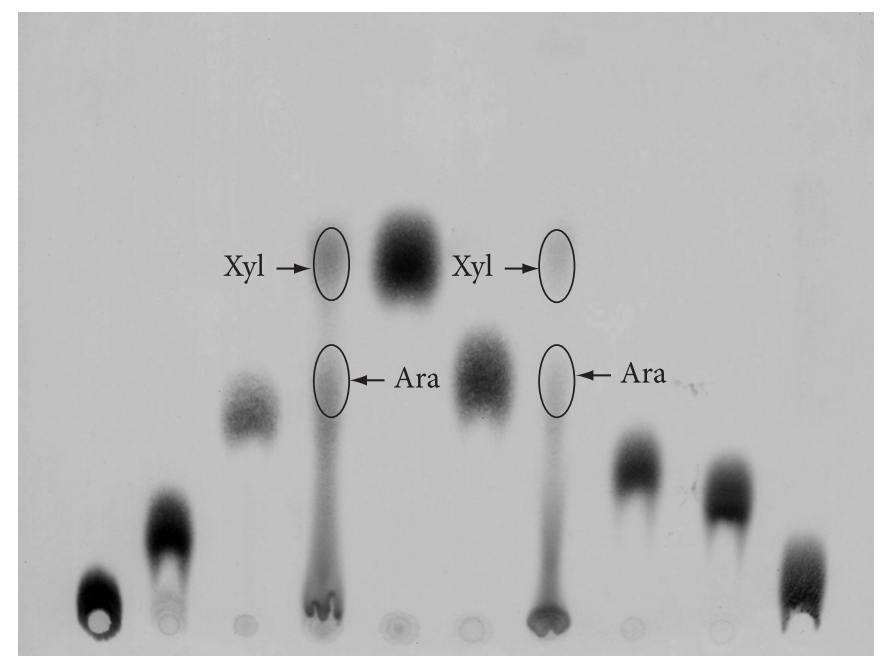

Figure 4. Chromatographic spots from Thin Layer Chromatography (TLC) for monosaccharides of the giant palm raw sample. Fractions isolated from the palm (WSP and CSP) were hydrolysed with $\mathrm{HCl}$ concentrated for 2 hours. The standards used were: galacturonic acid - GalAU, galactose - Gal, fructose - Fru, xylose - Xyl, arabinose - Ara, glucose - Glc, sucrose - Suc, gluconic acid - GlcAU. WSP = Water Soluble Pectin, CSP = Chelating Soluble Pectin as samples.
Table 3. Content of uronic Acid (galacturonic acid) of pectic polysaccharides extracted from four variety of Opuntia ficus indica of the dry season.

\begin{tabular}{lcc}
\hline \multicolumn{1}{c}{ Types of palm } & $\begin{array}{c}\text { Water soluble pectin } \\
(\text { WSP })-\left(\mathrm{mg}^{\left.-\mathrm{mL}^{-1}\right)}\right. \\
\text { Mean } \pm \text { Deviation }\end{array}$ & $\begin{array}{c}\text { Chelating soluble pectin } \\
(\mathrm{CSP})-\left(\mathrm{mg}^{-\mathrm{mL}^{-1}}\right) \\
\text { Mean } \pm \text { Deviation }\end{array}$ \\
\hline Tertiary giant palm & $2.48 \pm 0.000$ & $3.08 \pm 0.006$ \\
Quaternary giant palm & $2.92 \pm 0.000$ & $3.72 \pm 0.004$ \\
Tertiary round palm & $2.39 \pm 0.000$ & $3.90^{*} \pm 0.000$ \\
Quaternary round palm & $1.62 \pm 0.000$ & $3.83^{*} \pm 0.001$ \\
Tertiary copena F1 & $1.74 \pm 0.000$ & $4.37 \pm 0.000$ \\
Quaternary copena F1 & $1.57 \pm 0.001$ & $4.08 \pm 0.001$ \\
Tertiary clone 20 & $3.30 \pm 0.001$ & $5.49 \pm 0.000$ \\
Quaternary clone 20 & $1.03 \pm 0.000$ & $3.92 \pm 0.003$ \\
\hline${ }^{*}$ The mean do not differ between itself for the test of Tukey $(\mathrm{p}<0,05)$.
\end{tabular}

${ }^{\star}$ The mean do not differ between itself for the test of Tukey $(\mathrm{p}<0,05)$.

\section{Conclusions}

The tertiary cladode, as well as the cladodes of the dry season proved to have the highest content of carbohydrates, thus indicating that the palms of this season have a higher energy value.

The difference in the amount of carbohydrates in the four varieties could easily be attributed to the type of Opuntia.

As regards to the concentration of uronic acid, the results show that the tertiary cladodes present a higher amount of pectin than that of the quaternary cladodes, except for the giant palm since the pectic polysaccharides are a family of complex polysaccharides which contains D-galacturonic acid residues.

\section{Acknowledgment}

The authors are grateful to Agriculture Research Institute, especially the Experimental Station of Caruaru-PE, for providing the samples.

\section{References}

AMIM, E. S.; AWAD, O. M.; EL-SAYED, M. M. The mucilage of Opuntia ficus-indica Mill. Carbohydrate Research, v. 15, n. 1, p. $159-161,1970$.

ANDERSON, E.; SANDS, L.; STURGIS, N. Some plant gums of the South Western United States. American Journal of Pharmacology, v. 97, p. 589-592, 1925.

BERNFELD, P. Amylases, $\alpha$ and $\beta$. In: COLOWICH, S. P; KAPLAN, N. O. (Ed.). Methods in Enzimology. Academic Press, 1995. p. $149-158$.

CHANG, K. C. et al. Cultivar/location and processing methods affect the quality of sunflower pectin. Journal of Food Science, v. 59, n. 3, 602-605, 1994.

CRUZ, C. D.; REGAZZI, A. J. Divergência genética. In: Cruz, C. D.; Regazzi, A. J. (Eds.). Métodos biométricos aplicados ao melhoramento genético. Viçosa: Universidade Federal de Viçosa, 1994. p. 287-323.

DISCHE, Z. A new specific color reaction of hexuronic acids. Journal of Biological Chemistry, v. 167, n. 1, p. 189-198, 1974.

DORNELAS, M.; BARBOSA, A. M. Palma: cadeia produtiva da alimentação. Recife: SENAR-AR/PE, 2003. p. 8-9. 
DUBOIS, M. et al. Colorimetric method for determination of sugars, and related substances. Analytical Chemistry, v. 28, n. 3, p. 350-356, 1956.

FORNI, E.; PENCI, M.; POLESELLO, A. A preliminary characterization of some pectins from quince fruit (Cydonia oblonga Mill.) and prickly pear (Opuntia fícus indica) peel. Carbohydrate Polymers, v. 23, n. ?, p. 231-234, 1994. (n. 4)

HABIBI, Y. et al. Structural features of pectic polysaccharides from the skin of Opuntia ficus indica prickly pear fruits. Carbohydrate Research, v. 339, n. 6, p. 1119-1127, 2004.

HARLAY, V. Sur le mucilage du cactus à raquettes (Opuntia vulgaris Mill.). Journal of Pharmaceutical Chimica, v. 16, n. 6, p. 193-198, 1902.

LERCKER, G.; LERICI, C. R.; CAMPELA, P. Caratteri chimici del fico da Índia (Cactus Opuntia). Carboidrati e lipidi del frutto. Rivista Italiana delle Sostanze Grasse, v. 53, n. 10, p. 250-258, 1976.

MAJDOUB, H. et al. Polysaccharides from prickly pear peel and nopals of Opuntia ficus-indica: extraction, characterization and polyelectrolyte behavior. Polymer International, v. 50, n. 5, p. 552-560, 2001.

MALAININE, M. E. et al. Structure and morphology of cladodes and spines of Opuntia ficus indica. Cellulose extraction and characterisation. Carbohydrate Polymers, v. 51, n. 1, p. 77-83, 2003.

MAY, C. D. Industrial pectins: sources, production and applications. Carbohydrate Polymers, v. 12, n. 1, p. 79-99, 1990.
MEDINA-TORRES, L. et al. Rheological properties of the mucilage gum (Opuntia ficus indica). Food Hydrocolloids, v. 14, n. 5, p. 417-424, 2000.

MENEZES, R. S. C.; SIMÕES, D. A.; SAMPAIO, E. V. S. B. A palma no Nordeste do Brasil: conhecimento atual e novas perspectivas de uso. Recife: Editora Universitária/UFPE, 2005. 258 p.

NOVOSEL'SKAYA, I. L. et al. Trends in the science and applications of pectins. Chemistry of Natural Compounds, v. 36, n. 1, p. 1-10, 2000.

PARIKH, V. M.; JONES, J. K. N. Structure of Cholla Gum (Opuntia fulgida). Journal of Polymer Science, v. 11, n 1, p. 139-148, 1965.

PIMIENTA, E. El nopal tunero. México: Universidade de Guadajara, 1990. 246 p.

SAAG, L. M. K. et al. Cactaceae mucilage composition. Journal of the Science of Food and Agriculture, v. 26, n. 7, p. 993-1000, 1975.

SÁENZ, C. et al. Caracterización de harina de cladódios de nopal. In: CONGRESO INTERNACIONAL, 7.; CONGRESO NACIONAL SOBRE CONOCIMIENTO Y APROVECHAMIENTO DEL NOPAL. 5., 1997, Monterrey. Anais... Monterrey: 1997. p. 302-303.

SANDS, L.; KLAAS, R. Composition of cholla gum. I. the isolation of L-arabinose, D-galactose and L-rhamnose. Journal of American Chemical Society, v. 51, n. 11, p. 3441-3446, 1929. 